\title{
Taphonomic processes in terrestrial and marine environments
}

\author{
Michael Wuttke • Achim G. Reisdorf
}

Received: 10 January 2012 / Accepted: 11 January 2012 /Published online: 1 February 2012

(C) Senckenberg Gesellschaft für Naturforschung and Springer 2012

The focus of this special issue is on the taphonomy of fossil vertebrates, as well as on uniformitarian experimental studies. In a palaeontological sense, taphonomy has the focus on a very long time scale, with different taphonomic filters, that dumps high-frequency signals by causes of death, decomposition, embedding and early diagenesis (Briggs 2010; Efremov 1940; Lyman 2010; Martin 1999). Due to their highly differentiated anatomical bauplan, vertebrates are subject to complex mechanisms of decomposition which are linked with each other in manifold ways. Therefore, it must be the intention of taphonomical studies to differentiate basic mechanisms of decomposition and comprehend their sequence as well as their interactions with the deposition environment.

The first key to understanding the taphonomy of vertebrates is therefore to reconstruct the context in which burial data are created (e.g. Roksandic 2002). Apart from climatic factors (e.g. temperature of environment), which, not least of all, also control the sedimentation regime, it is essential to the potential of fossilisation of organic remains whether the decomposition, as well as the bedding of a carcass, took place in a subaerial or subaquatic environment. However, the habitat, the place of dying, as well as the environment of

This article is a contribution to the special issue "Taphonomic processes in terrestrial and marine environments".

M. Wuttke $(\bowtie)$

Referat Erdgeschichte, Generaldirektion Kulturelles Erbe

Rheinland-Pfalz,

Große Langgasse, 29,

55116 Mainz, Germany

e-mail: michael.wuttke@gdke.rlp.de

A. G. Reisdorf

Geologisch-Paläontologisches Institut, Universität Basel,

Bernoullistrasse 32,

4056 Basel, Switzerland

e-mail: achim.reisdorf@unibas.ch the decomposition and bedding of vertebrates are rarely identical. Therefore, it is absolutely necessary for reconstructing the taphonomic history of vertebrates to make a conscientious documentation of the geological and palaeontological context.

Last but not least, a critical evaluation of possible scenarios of the cause of death and the processes of decomposition and bedding, as well as their attendant circumstances, makes it possible to draw valuable conclusions concerning the environment of present and past habitats. Taphonomic aspects therefore have an explosive nature as far as economy and environmental politics are concerned, which has already been given attention at the time of the beginning of uniformitarian research (e.g. Wasmund 1935, 48 p.; Wiman 1914). In connection with this, an observation note of Monnett and Gleason (2006) about four dead polar bears floating in open water of the Arctic Ocean in 2004 recently became a rallying point for campaigners seeking to blunt the impact of global warming (e.g. Morell 2011; Reardon 2011; Reich 2011).

A second key to the reconstruction of the taphonomic fate of fossil vertebrates is their quality and quantity in the fossil record. A multitude of intrinsic and extrinsic factors which influenced a carcass up to its complete and final bedding can be deducted from the completeness, the degree of disarticulation and from the relative position as well as from the grade of scattering and modifications of the vertebrates' skeletal elements (e.g. Lyman 1994). Uniformitarian experiments on the decomposition of vertebrates which give evidence of the timeline of decomposition and the hardiness of different tissues against decay may furnish suitable clues here.

In our view, just in the research of the taphonomy of fossil vertebrates, too little attention has been given so far to the complex interactions between the anatomy of soft tissue and skeleton of a carcass. Vertebrates have certain taphonomic predispositions because of their specific bauplan, their 
functional morphological laws and because of their age and sex. These predispositions may result in typical taphonomic positional relation and dislocation, as well as in certain patterns of disarticulation of skeletal elements (e.g. KielanJaworowska and Hurum 2006; Schäfer 1972). However, the current bodily constitution of a vertebrate at death (e.g. body mass, extent of filling of the intestines, filling condition of the lungs, pathology and cause of death) can lead to variations or even significant deviations in the positional relations and patterns of disarticulation of skeletal elements. In the end, all the modifications of chemical and physical parameters which take place through autolysis and heterolysis in the carcass have the potential to cause changes of position up to disarticulation of anatomical unities.

As a third key to solve taphonomical problems, it is essential not only to include the multitude of scientific disciplines of human medicine and veterinary medicine, but also those which deal with taphonomical questions in a practice-oriented manner (e.g. nutrition science, forensic entomology, catastrophe management, chemical and biological engineering; e.g. Andersson et al. 1995; Benecke 2008; Bonhotal et al. 2006; Coghlan 1998; Dittrich and Luttge 2008; Lloyd et al. 2008; Lochner et al. 1980; Ryon et al. 2000; Sledzik and Rodriguez 2002; de Ville de Goyet 2004; Wilhelm et al. 2009). The pioneers of taphonomical research already used the store of knowledge of that sort of disciplines (e.g. Wasmund 1935; Weigelt 1927; Wiman 1914, 1942). This is especially true for forensic medicine. For more than a hundred years, this scientific discipline has been striving to gain information about decomposition processes in highly different environments by observation, dissections and experiments (e.g. Neufeld and Scheck 2010). In the future, this knowledge must be increasingly exploited for palaeontology.

In its multidisciplinary approach, the eight articles of the special issue provide decomposition experiments, partly documented by X-ray and high-resolution micro-computed tomography (CT), insights into new approaches to analyse fossil skeletons by using forensic methods and findings, a comparison of the taphonomic fate of marine lung-breathing fossil reptiles and extant mammals and the taphonomic history of marine and freshwater fishes as well as terrestrial reptiles and mammals.

Richter and Wuttke give a report on a uniformitarian, subaquatic, decomposition experiment which was performed on a carcass of the iguanid Oplurus cuvieri. The goal was to get information about the invisible subintegumental disarticulation process of the skeleton; therefore, this process was continuously documented by X-rays. These results are used to reconstruct the taphonomic history of well-preserved lizard bone aggregates from the Lower Cretaceous (Barremian) coals of Uña (eastern Spain).

Schwermann et al. provide an overview on forensic radiographic examinations by CT (Virtopsy), which have evolved into a new approach for uniformitarian experiments, which allow a continuous insight into the decay process of a vertebrate carcass. The authors investigated the controlled decay of a dormouse Eliomys quercinus carcass in detail, using for the first time high-resolution micro-CT, to elucidate the taphonomy of the middle Eocene apatemyid mammal Heterohyus from Messel. This study was enforced by the lack of information available about internal decay processes affecting the coherence of the skeletal system. The combination of different indicators of this documented decomposition process, the lack of skeletal disintegration in Heterohyus and palaeoenvironmental data lead to the assumption that Heterohyus went through an adipocere-forming phase at the bottom of Lake Messel before embedding.

Smith and Wuttke for the first time present a study on taphonomic phenomena among the reptiles in the maar lake of Messel (middle Eocene), which are virtually unstudied. The iguanid Geiseltaliellus maarius (able to urotomize its tail) is the most common lizard species in Messel. Specimens of $G$. maarius can be divided into three preservation classes, one of which is distinguished purely by decompositional phenomena: early sinking, floating before sinking and eruption of intracoelomically builded putrefaction gases. For the first time, the hypothesis of adipocere formation in carcasses is given for the Fossillagerstätte Messel.

Reisdorf et al. present a review and own data on what happens after the death of fossil and extant marine lungbreathing tetrapods in seawater. The authors examined the taphonomy and sedimentary environment of numerous ichthyosaur skeletons and compared them to living marine tetrapods, principally cetaceans. Contrary to the claims of palaeontolgists and neontologists, the carcasses of ichthyosaurs did not float at the surface after death and sank subsequently after leakage of putrefaction gases (i.e. carcasses do not explode and spread skeletal elements). Reisdorf et al. argue that the normally slightly negatively buoyant carcasses of ichthyosaurs would have sunk to the sea floor and risen to the surface only when they remained in shallow water (low hydrostatic pressure) above a certain temperature and at a low scavenging rate.

Beardmore et al. give a comparison on taphonomic models for a dataset of Steneosaurus (Mesoeucrocodylia; Thalattosuchia) from the Toarcian Posidonienschiefer Formation (Lower Jurassic, Germany), and that of thalattosuchians from other Jurassic localities (Peterborough and Yorkshire, UK; Nusplingen, Germany). The skeletal taphonomy of the specimens is assessed in terms of the articulation and completeness of nine skeletal units. In the Posidonienschiefer Formation, loss of fidelity occurred primarily as individuals lay on the sediment, and disarticulated elements tended to remain in the vicinity of the carcass. Specimens from other localities broadly follow the same taphonomic pathway, in all Lagerstätten weak to stronger bottom currents removed smaller skeletal elements. 
Chellouche et al. present qualitative as well as quantitative taphonomic investigations on fishes (primarily of the genus Tharsis) of four different taphofacies, established by means of cluster analysis, out of the Upper Kimmeridgian Wattendorf Plattenkalk (South Germany). The different taphofacies mark a change from a palaeoenvironment with only small extrinsic disturbing factors to a palaeoenvironment characterised by greater disturbance (e.g. bottom currents, fluctuating salinity). Exceptional preservation of soft tissues is displayed, besides typical phosphatisation, through iron oxide permineralisation within one specimen of Palaeohirudo? sp.

Reisdorf and Wuttke give a critical review on the palaeoenvironment of the famous South Franconian plattenkalks of the Upper Jurassic Solnhofen Archipelago (Germany) and reevaluate Moodie's (1918) hypothesis that long-necked, longtailed tetrapods have died by cerebral disorder, in which their necks and tails were recurved over the animals' backs. This 'opisthotonic posture hypothesis' is re-evaluated by analysing the non-avian theropods Compsognathus longipes and Juravenator starki from those plattenkalks and by conducting decay experiments with the extant domestic fowl Gallus gallus L. Additionally, analyses of constructional morphological constraints of the fossil and extant theropods reveal that the opisthotonic posture is not a peri- but a postmortem phenomenon. Analyses concerning the palaeoenvironment of the basins of the Solnhofen Archipelago show that the conditions of deposition of the single basins cannot be considered to be similar, even inside a time slice.

Hellawell and Orr finally report on decay experiments of the extant taxon Carassius auratus auratus over a 6-month period, to decipher the taphonomy of abundant fossil fishes, preserved in exquisite detail, from the Fossil Lake, Green River Formation, Wyoming (USA), a late Early Eocene Lagerstätte. Various scenarios approximating conditions in the Eocene lake were replicated in the laboratory. The experiments clearly indicate that decay in a quiet-water environment is, by itself, insufficient to explain the consistently high fidelity preservation of Green River fish. Therefore, the authors propose that microbial mats at the sediment-water interface were key; fish carcasses became adhered to the sediment surface inhibiting disarticulation and loss of bones. This article will be published as an additional contribution in a subsequent regular issue.

\section{References}

Andersson A, Ronner U, Granum PE (1995) What problems does the food industry have with the spore-forming pathogens Bacillus cereus and Clostridium perfringens? Int J Food Microbiol $28: 145-155$

Benecke M (2008) A brief survey of the history of forensic entomology. Acta biologica Benrodis 14:15-38
Bonhotal J, Harrison E, Schwarz M (2006) Evaluating pathogen destruction in road kill composting. BioCycle 47:49-51

Briggs DEG (2010) Decay distorts ancestry. Nature 463:741-743

Coghlan A (1998) From a watery grave. Bacteria that feast on whale bones reveal the secret of cool washes. New Sci 157:24

de Ville de Goyet C (2004) Epidemics caused by dead bodies: a disaster myth that does not want to die. Pan Am J Public Health 15:297-299

Dittrich M, Luttge A (2008) Microorganisms, mineral surfaces, and aquatic environments: learning from the past for future progress. Geobiology 6:201-213

Efremov JA (1940) Taphonomy: a new branch of geology. Pan Am Geol 74:81-93

Kielan-Jaworowska Z, Hurum J (2006) Limb posture in early mammals: sprawling or parasagittal. Acta Palaeontol Pol 51:393-406

Lloyd JR, Pearce CI, Coker VS, Pattrick RAD, van der Laan G, Cutting R, Vaughan DJ, Paterson-Beedle M, Mikheenko IP, Yong P, Macaskiep LE (2008) Biomineralization: linking the fossil record to the production of high value functional materials. Geobiology 6:285-297

Lochner JV, Kauffman RG, Marsh BB (1980) Early-postmortem cooling rate and beef tenderness. Meat Sci 4:227-241

Lyman RL (1994) Vertebrate taphonomy. Cambridge manuals in archaeology. Cambridge University Press, Cambridge

Lyman RL (2010) What taphonomy is, what it isn't, and why taphonomists should care about the difference. J Taphonomy 8:1-16

Martin RE (1999) Taphonomy: a process approach. Cambridge University Press, New York

Monnett C, Gleason JS (2006) Observations of mortality associated with extended open-water swimming by polar bears in the Alaskan Beaufort Sea. Polar Biol 29:681-687

Moodie RL (1918) Studies in paleopathology. III. Opisthotonus and allied phenomena among fossil vertebrates. Am Naturalist 52:384-394

Morell V (2011) Senator Inhofe has questions about polar bear researcher Charles Monnett. ScienceInsider. http://news.sciencemag.org/ scienceinsider/2011/08/senator-inhofe-has-questions-abo.html. Accessed 10 Aug 2011

Neufeld P, Scheck B (2010) Making forensic science more scientific. Nature 464:351

Reardon S (2011) Suspended polar bear researcher defended by advocates. ScienceInsider. http://news.sciencemag.org/scienceinsider/2011/07/ suspended-polar-bear-researcher.html. Accessed 29 Jul 2011

Reich ES (2011) Bear researcher frozen out. Nature 476:16-17

Roksandic M (2002) Position of skeletal remains as a key to understanding mortuary behavior. In: Haglund WD, Sorg MH (eds) Advances in forensic taphonomy method, theory and archaeological perspectives. CRC Press, Boca Raton, pp 99-117

Ryon MG, Beauchamp JJ, Roy WK, Schilling E, Carrico BA, Hinzman RL (2000) Stream dispersal of dead fish and survey effectiveness in a simulated fish kill. Trans Amer Fish Soc 129:89-100

Schäfer W (1972) Ecology and palaeoecology of marine environments. University of Chicago Press, Chicago

Sledzik PS, Rodriguez WC III (2002) Damnum fatale: the taphonomic fate of human remains in mass disasters. In: Haglund WD, Sorg MH (eds) Advances in forensic taphonomy method, theory and archaeological perspectives. CRC Press, Boca Raton, pp 321-330

Wasmund E (1935) Die Bildung von anabituminösem Leichenwachs unter Wasser. Schr Brennstoffgeol 10:1-70

Weigelt J (1927) Rezente Wirbeltierleichen und ihre paläobiologische Bedeutung. Max Weg, Leipzig

Wilhelm SI, Robertson GJ, Ryan PC, Tobin SF, Elliot RD (2009) Reevaluating the use of beached bird oiling rates to assess long-term trends in chronic oil pollution. Mar Pollut Bull 58:249-255

Wiman C (1914) Über die paläontologische Bedeutung des Massensterbens unter Tieren. Paläont Z 1:145-154

Wiman C (1942) Über ältere und neuere Funde von Leichenwachs. Senckenbergiana 25:1-19 